\title{
Argemone species: Potential source of biofuel and high-value biological active compounds
}

\author{
Alejandra Anahi Martínez-Delgado ${ }^{1}$, José de Anda ${ }^{{ }^{\dagger}}$, Janet María León-Morales ${ }^{2}$, Juan Carlos Mateos-Díaz ${ }^{3}$, \\ Antonia Gutiérrez-Mora ${ }^{4}$, José Juvencio Castañeda-Nava ${ }^{4}$ \\ ${ }^{1}$ Unidad de Tecnología Ambiental, Centro de Investigación y Asistencia en Tecnología y Diseño del Estado de Jalisco, A.C. (CIATEJ), Av. Normalistas \\ 800 Colinas de la Normal C.P.4270 Guadalajara, Jalisco, México \\ ${ }^{2}$ CONACYT - Centro de Investigación y Asistencia en Tecnología y Diseño del Estado de Jalisco, A.C., México \\ ${ }^{3}$ Unidad de Biotecnología Industrial, Centro de Investigación y Asistencia en Tecnología y Diseño del Estado de Jalisco, A.C. (CIATEJ), Camino \\ Arenero 1227, El Bajío, C.P. 45019 Zapopan, Jalisco, México \\ ${ }^{4}$ Unidad de Biotecnología Vegetal, Centro de Investigación y Asistencia en Tecnología y Diseño del Estado de Jalisco, A.C. (CIATEJ), Camino Arenero \\ 1227, El Bajío, C.P. 45019 Zapopan, Jalisco, México
}

\section{ABSTRACT}

The Argemone genus includes weed species of great importance in traditional medicine due to biological activities attributed to secondary metabolites, mainly alkaloids, distributed in all tissues of this species. In addition, their seeds contain a large amount of oil (30 to $40 \%)$. For this reason, several authors have discussed the potential of this species as a non-edible source to produce multi-purpose raw materials and a low cost-crop for example in the production of biofuels such as biodiesel. Argemone species grows in poor soils with low water and nutrient requirements. This makes the Argemone species an attractive economical and environmentally friendly candidate for biofuels production. Furthermore, the Argemone species can also provide high-value by-products for the agrochemical and pharmaceutical industry. In this work, we compiled the ethnomedical information, biochemical features, and biofuel production efforts that have been published by testing different Argemone species, in order to compare the research efforts and analyze its biotechnological potential. After analyzing the literature, we conclude that the genus has great potential for high-value pharmaceutical products and energy production purposes, and also to control plant pests. We also consider that other species of the genus may have also potential applications in this field.

Keywords: Alkaloids, Argemone, Argemone oil, Bioenergy, Biofuels

\section{Introduction}

Weeds are invasive plants adapted to hostile conditions, they can grow in disturbed areas, with low nutritional and moisture requirements. Nevertheless, they have had great importance in traditional medicine due to their high content of secondary metabolites [1].

Several reports point out that a large part of the components of pharmaceutical products are derived from weeds [2]. Papaveraceae is an ethnopharmacologically important family considered as a weed, with 44 genera and over 760 species. Among them, Argemone genus is represented mainly by Argemone mexicana and Argemone ochroleuca, commonly known as the Mexican prickly poppy, flowering thistle, "cardo santo" or "chicalote". Both species are native to Mexico and have been used for the treatment of several diseases around the world, including skin diseases (leprosy, warts), tumors, microbial infections, malaria, etc. [3-5].

Argemone species have economic potential due to their oil content in seeds (30 to $40 \%$ ) and therapeutic potential. The biological activities reported can be attributed to the high content of alkaloids throughout the plant, mainly benzylisoquinoline alkaloids [4, 6-9]. Alkaloids present in Argemone species include protopine, berberine, sanguinarine, among many others $[3,10,11]$.

On the other hand, weeds have been identified as a source of non-edible crops utilized for the production of multi-purposes
This is an Open Access article distributed under the terms of the Creative Commons Attribution Non-Commercial License (http://creativecommons.org/licenses/by-nc/3.0/) which permits unrestricted non-commercial use, distribution, and reproduction in any medium, provided the original work is properly cited.

Copyright (C) 2022 Korean Society of Environmental Engineers
Received November 12, 2020 Accepted January 30, 2021

${ }^{\dagger}$ Corresponding author

E-mail: janda@ciatej.mx

Tel: +5233 33455200 (ext. 2131)

ORCID: 0000-0001-9521-5968 
raw materials with potential to produce energy [12-14].

In the last decade, several studies reported the use of Argemone species as a candidate for low-cost crop to produce energy, due to its capacity to grow in poor soils, rough terrain, irregular rainfall, without specific environment variables. Furthermore, they can also provide high-value by-products $[15,16]$, making economically feasible the production of biofuels under the bio-refinery concept [8, 15, 17].

Patents in energy areas report the use of transesterified oil of A. mexicana as an additive (WO 2011/145101 A1, 2011/0283605 A1)

The first report on energy production using Argemone oil was in 2010 by the group of Singh and Singh at Devi Ahilya University (India). They detailed a process to generate and extract esters and biogas from $A$. mexicana seeds $[8,17]$. Nowadays, several methods for biodiesel production have been published, including those using other species such as $A$. ochroleuca [18].

Many reviews about $A$. mexicana have been published focus on its chemical composition and pharmaceutical potential. So far it has not been found comparative studies with other species or the energy potential of the genus.

This article synthesizes and compares the peer reviewed published information related to the exploitation of the different species of Argemone genus, with an energy and ethnobotanical approach. The aim of compile the published information of all species of the genus was to compare and analyze the potential of new multi-purpose species and the perspectives of their use in the biofuel industry.

\section{Argemone Genus}

The first species of Argemone reported in the literature was $A$. mexicana, described as Papaver spinosum by Caspar Bauhin in 1595 and illustrated by Gerard in 1597. It was known by other names up to 1694 when was registered with the current name by Tournefort [19].

Argemone has been considered a genus with taxonomic inconsistencies from its initial descriptions. The first revision of the genus was attributed to Sir David Prain in 1895, whereas Ownbey [19] published a biography of the genus restricted to North America and Western India in 1958. The species A grandiflora, A platyceras, $A$. polyanthemos and some others have been cultivated occasionally according to Ownbey, besides pointing out that $A$. sanguinea, $A$. polyanthemos and $A$. aenea are the best species for gardens.

\subsection{Taxonomy [20]}

Kingdom: Plantae

Subkingdom: Traqueobionta

Superdivision: Spermatophyta

Division: Magnoliophyta

Class: Magnoliopsida

Subclass: Magnoliidae

Order: Papaverales

Genus: Argemone

The genus Argemone is originating from America, currently with presence in different countries outside its natural range of distribution. Karnawat [21] mentions that the genus comprises about 30 species. According to Ownbey [19, 22], there are 23 species in North America, highly distributed throughout Mexico and Central America, with the exception of very high areas, generally around 2400 meters above sea level. There are 4 species in South America, distributed in Paraguay, Chile, Argentina, Uruguay, Bolivia, and Panama.

In the region of Saudi Arabia, the first record of the genus was published in 1974 by Migahid, later Hussein reported in 1983 A. mexicana in desert areas; furthermore, $A$. ochroleuca have also been reported in the same country (as cited by Moussa [16]).

\subsection{Distribution}

Argemone species are plants adapted to semi-warm, semi-dry and temperate climates from sea level up to 2750 meters above sea level [23], they are tolerant to low temperatures and droughts [24]. They grow in abandoned agricultural lands, in agricultural areas, or on roadsides, associated with arid zones and low deciduous forest [20]. The presence of some species has also been reported in deciduous and evergreen tropical forests, xerophytic scrub, spiny forest, pine, mixed pine-oak and juniper [23].

$A$. mexicana and $A$. ochroleuca are native to America and can share habitats in tropical and subtropical areas where they are distributed around the world [16]. They are distributed mainly in the southern zone of North America [1]. However, these species are not restricted to any of 23 environmental variables such as frequency of rainfall, altitude, or soil type [16]. They are able to grow in regions with extreme conditions such as limited rainfall, high temperatures, and land with high salt concentrations, e.g. Saudi Arabia where sodium content varies from 0.15 to $2.25 \mathrm{meq} / \mathrm{L}$ [7, 16, 25].

A. mexicana and $A$. ochroleuca have been introduced in some regions such as Australia, India and West Africa [3].

\subsection{Description}

The taxonomic keys for the identification of the different species of Argemone can be found in Flora del Bajío y de Regiones Adyacentes [26], Flora de Veracruz [27] or Monograph of the genus Argemone for North America and the West Indies [19]. Classical references are widely used in current works. Distinctive features of the genus are mentioned in this work.

The different species of the genus except for $A$. grandiflora have thorny stems, leaves and, capsules [28]. A. ochroleuca has a whitish-green, with intense glaucous color, meanwhile, $A$. mexicana also presents a slightly glaucous tone with a more intense green $[21,29]$.

The leaves are alternate with serrated margins that ending in a spine. The bud forms are variable, they could be lobed, elliptical, spherical, or obovate. According to Ownbey (as cited by Peña [22]) the number of sepals varies from 2 to 6 , being usually 3 , with a corniculate appendage at the apex, the shape of the horns of the sepals is useful to distinguish them.

The flowers of Argemone species are actinomorphic, with 6 or rarely 9 petals, in $A$ ochroleuca are 6 elliptical to obovate or obcuneiform, whereas petals of $A$. albiflora, $A$. munita and $A$. gracilenta are obovate or suborbicular $[21,28]$.

The color of the flower ranges from yellow to white, including lavender color. Flowers are hermaphrodites. The anthers are linear of two dehiscent cells, the pistils are composed of a stigma, a short style, the stamens in the different species are numerous, 


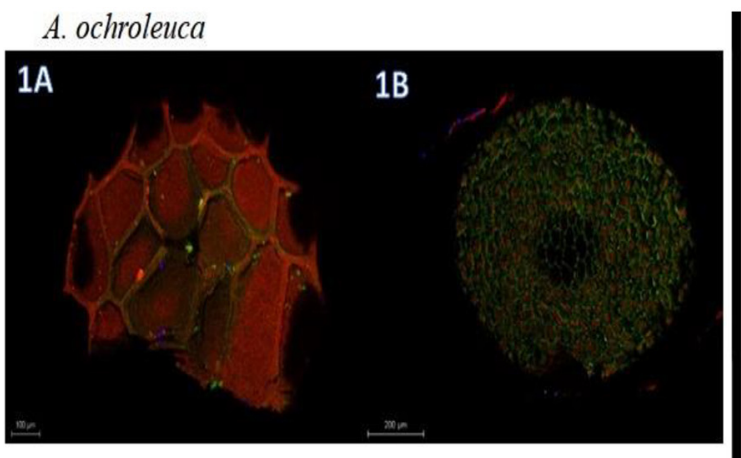

\section{A. mexicana}
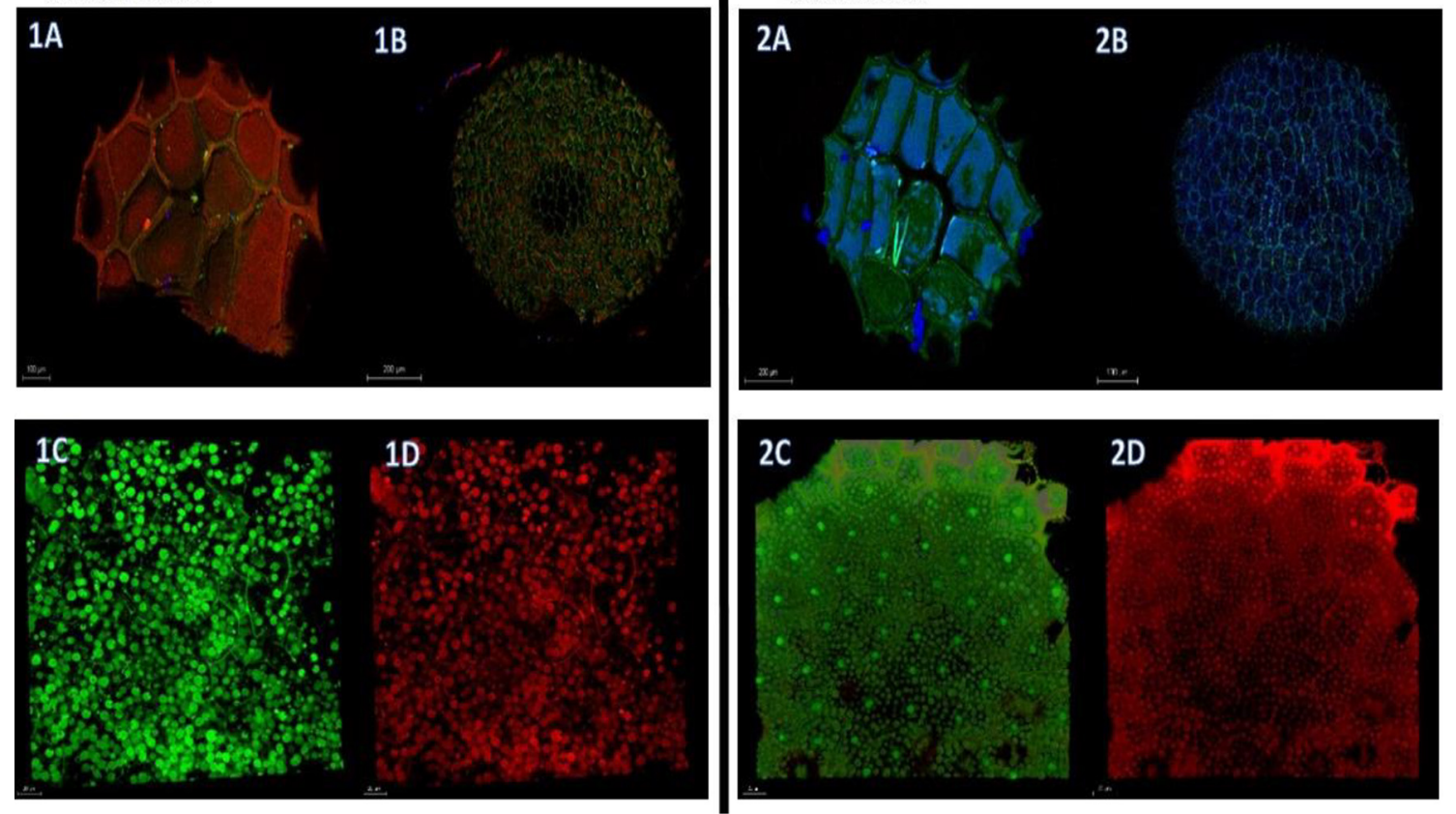

Fig. 1. Seeds of $A$. mexicana and $A$. ochroleuca in a fluorescence confocal microscope. Comparative using a laser with the same wavelength in both species $A$. ochroleuca (left) and A mexicana (right). With green, red and blue channels and merged images of the channels, showing autofluorescence in seeds due to the alkaloids composition. $1 \mathrm{~A}$ and $2 \mathrm{~A}$ seed testa surface (bars $=200 \mu \mathrm{m}$ ), $1 \mathrm{~B}$ and $2 \mathrm{~B}$ seed endosperm (bars $=200 \mu \mathrm{m}), 1 \mathrm{C}, 1 \mathrm{D}, 2 \mathrm{C}$ and 2D (bars $=20 \mu \mathrm{m})$.

the number varies according to the species, Karnawat and Malik mention that $A$. mexicana has from 30 to 50 while $A$. ochroleuca from 20-75 [5, 22, 28, 30].

The different Argemone species produce a dry dehiscent fruit or capsules with 3-6 carpels and a great number of seeds. The capsules could show a narrowly elliptical-oblong, lanceolate, or ovate form [22, 28].

The seeds of Argemone are subspherical or slightly conical with a size between 1-2.5 mm. A slender peak often prominent is formed in the micropyle and the testa reticulate shows surface depressions [19, 28, 29]. Seeds cannot be visually differentiated, the measures of the depressions have not a taxonomic value because their color and size range is practically the same [21].

The roots of the Argemone species have a strong and slightly branched tap root. The primary root of $A$. polyanthemos can penetrate up to more than $60 \mathrm{~cm}$ deep, whereas other species develop lateral roots [5, 19].

Argemone seeds, present a composition of isoquinoline alkaloids, which exhibits properties of auto-fluorescence due to their molecular structure. The absorptions and emissions properties of sanguinarine are associated with the molecular structure acquired when dissolved in solution. The ionic form of sanguinarine as quaternary ammonium salt corresponds to a maximum emission of about 580 $\mathrm{nm}$ while the non-ionic form has a maximum peak at $450 \mathrm{~nm}$ [31].

In this work, we confirmed by examination using a fluorescence confocal microscope that the seeds from $A$. mexicana and $A$. ochroleuca show auto-fluorescence as shown in Fig. 1. This property can be applied as an important tool to evaluate the physiological state of the seed, as Yuan et al. [32] indicate

The presence of autofluorescent molecules in different structures can be used also as a tool for morphological studies and to study the stress response to environmental stress, contributing to the assessment of the physiological state of the seeds or other tissues. This is possible since the chemical profile, e.g. alkaloid concentration changes with environmental factors such as exposure to light, soil fertility, soil moisture, among others [33].

The most widely studied species of the genus are $A$. mexicana and $A$. ochroleuca which are closely related because they present great morphological similarities which frequently lead to taxonomic confusions; but in fact, they differ in the shape of flowers, shape of bud, and petals color, showing bright yellow and pale yellow flowers respectively [21, 28, 29] as shown in Fig. 2.

$A$ ochroleuca Sweet was classified as a lower taxon of $A$ mexicana until 1903 (as cited by Ownbey [19]) when Rose [34] gave to $A$. ochroleuca a full specific rank. Some authors suggest that could have emerged as an autotetraploid of $A$. mexicana, because of its resemblance and having a degree of crosslinking [19, 21]. However, the molecular phylogenetic analysis revealed that these species have evolved independently [21].

\section{Ethnobotanical Importance}

Argemone species have been used in traditional medicine from ancient cultures. A. mexicana was described in the "De la Cruz Badiano" Codex, a compilation about the traditional use of the 


\section{A. ochroleuca}

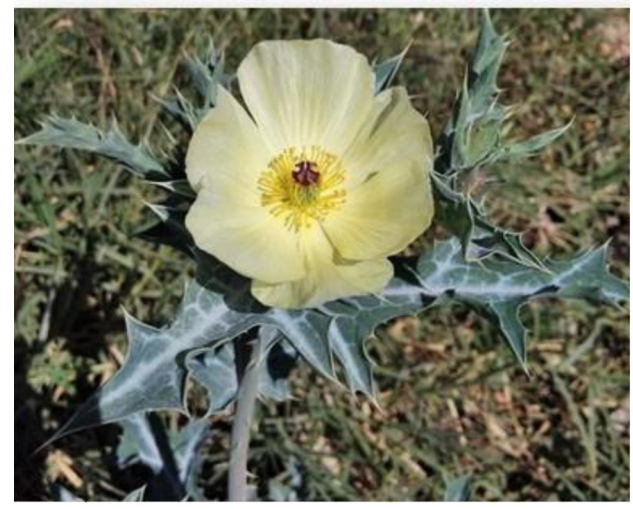

A. Mexicana

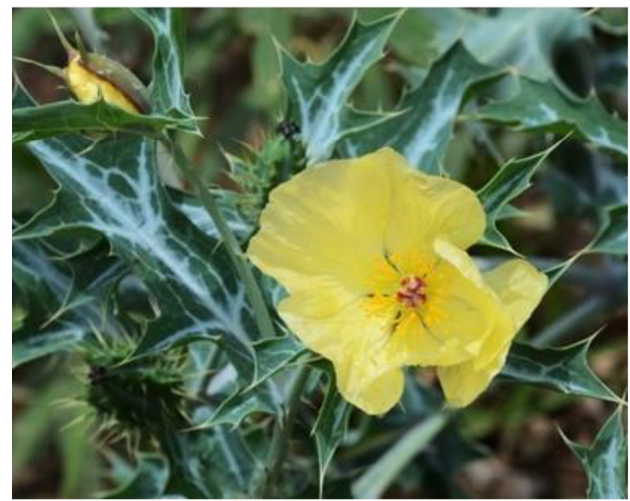

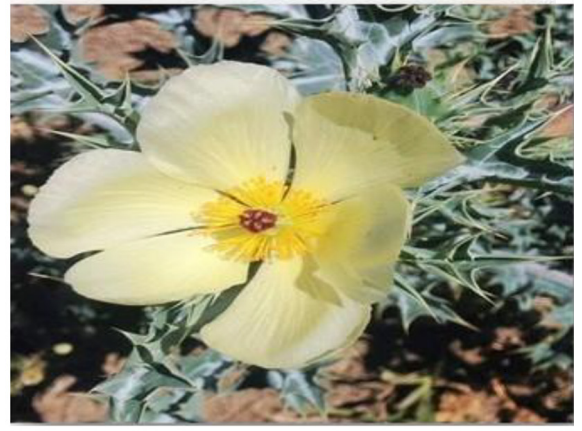

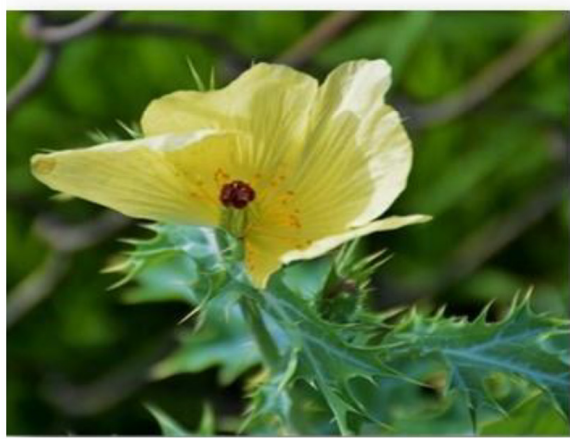

Fig. 2. A. ochroleuca and A. mexicana. A. ochroleuca has a pale yellow color while A. mexicana has more intense colors.

medicinal plants by Aztecs [35]. According to the ethnobotanical interpretation of archaeobotanical and iconographic records, $A$. ochroleuca subsp. stenopetala was identified as a medicinal plant potentially used by Teotihuacan culture [36].

In Mexico, infusions of aerial parts of the plant are still used in the treatment of eye such as conjunctivitis, respiratory, dermatological, and oral infections, as well as for wounds. Some communities such as Tepotzotlán (State of Mexico), Ahuacatlán (Nayarit), among others also use these infusions because of their stimulant and hallucinogenic effects [37-39].

Other medicinal properties of Argemone species have been reported in different Latin American countries, such as analgesic use of $A$. subfusiformis in Argentina [19, 40], or in Bolivia, against cough and cold [41].

Moreover, Argemone species are also part of the traditional medicine of Saudi Arabia [42], and India (Tribe in Myeong area, Assam); where they have been used against diseases such as dropsy, jaundice, as well as eye and skin infections such as scabies and leprosy $[3,43]$.

\subsection{Biological Activity}

Several biological activities have been reported to $A$. mexicana, A. ochroleuca, A. gracilenta, A. subfusiformis and, A. platyceras such as antimicrobial, insecticidal, anti-inflammatory, cytotoxic, and anti-asthmatic [1, 3, 41, 44-47].
Since the biological activity could be modified by the extraction procedure, different raw tissues or extracts of Argemone species have been tested. Table 1 summarizes the plant part (leaves, stem, flowers, or whole plant), type of extract, and the biological model evaluated including rodents, insects (eggs, larvae, and adults), microorganisms (bacteria, fungi, and protozoal) as well as cancer cell lines.

As indicated in Table 1, crude extracts of different polarity (dichloromethane, ethyl acetate, acetone, ethanol, methanol, water, and hydroalcoholic mixture) of Argemone species have been tested on a variety of important pathogens such as the protozoan parasites P. falciparum and T. cruzi, which cause serious diseases such as malaria and Chagas; gram-positive (Bacillus subtilis and Staphylococcus aureus) and gram-negative (Escherichia coli and Vibrio cholerae) bacteria, as well as yeast of Candida genus $(C$. albicans, C. glabrata, C. krusei, and C. tropicalis).

Insecticidal potential also has been evaluated in different species, for example against Aedes aegypti, responsible for the transmission of Dengue virus and yellow fever. In this species, Vidal et al. [57] report $100 \%$ mortality in larvae with $76.8 \mathrm{mg} / \mathrm{L}$ extract of $A$. subfusiformis after $12 \mathrm{~h}$ of exposure, with a lethal concentration LC50\% of $6.24 \mathrm{mg} / \mathrm{L}$ after $48 \mathrm{~h}$.

The ethanolic extracts of $A$. ochroleuca have an insecticidal effect on Tribolium castaneum. Bakhashwain and Alquiashi [54] report $78.9 \%$ mortality after $6 \mathrm{~d}$ of treatment (800 ppm). The ethanolic extract of this species also affects the feeding and larval 


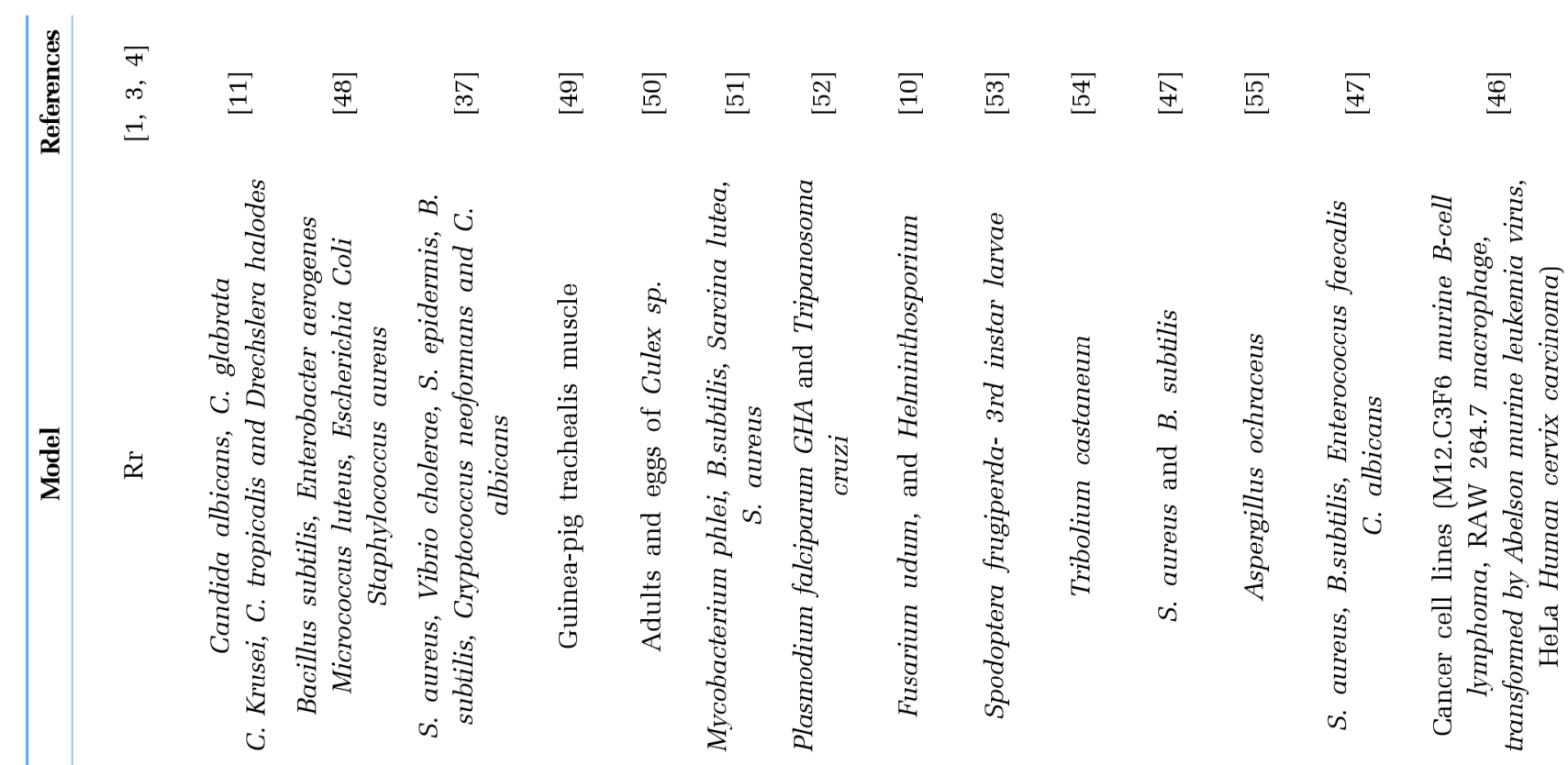

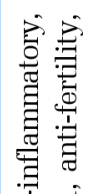

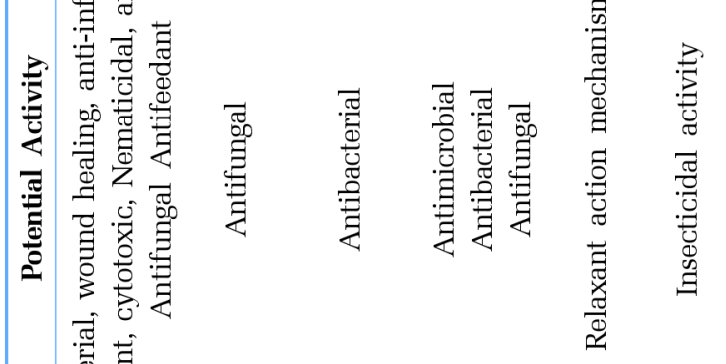

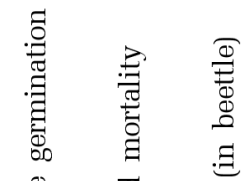

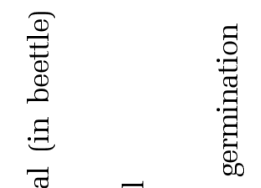

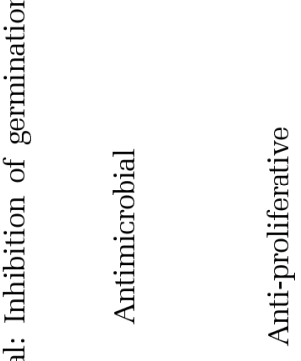

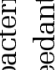

尊悬

2 平

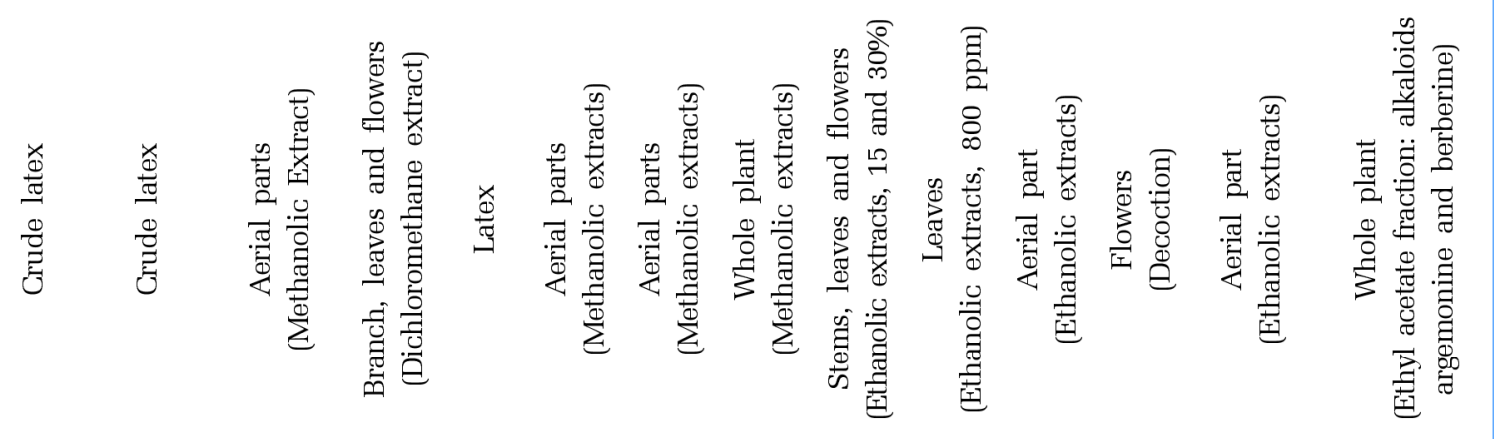

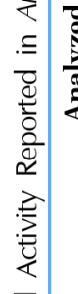

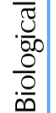

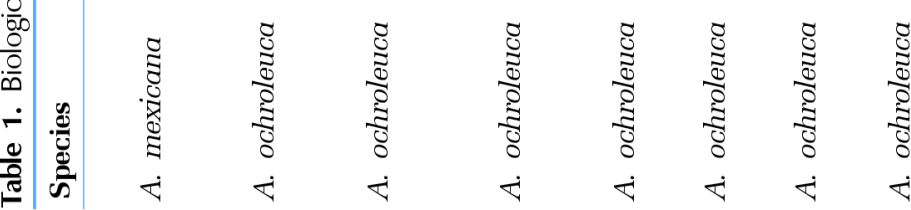

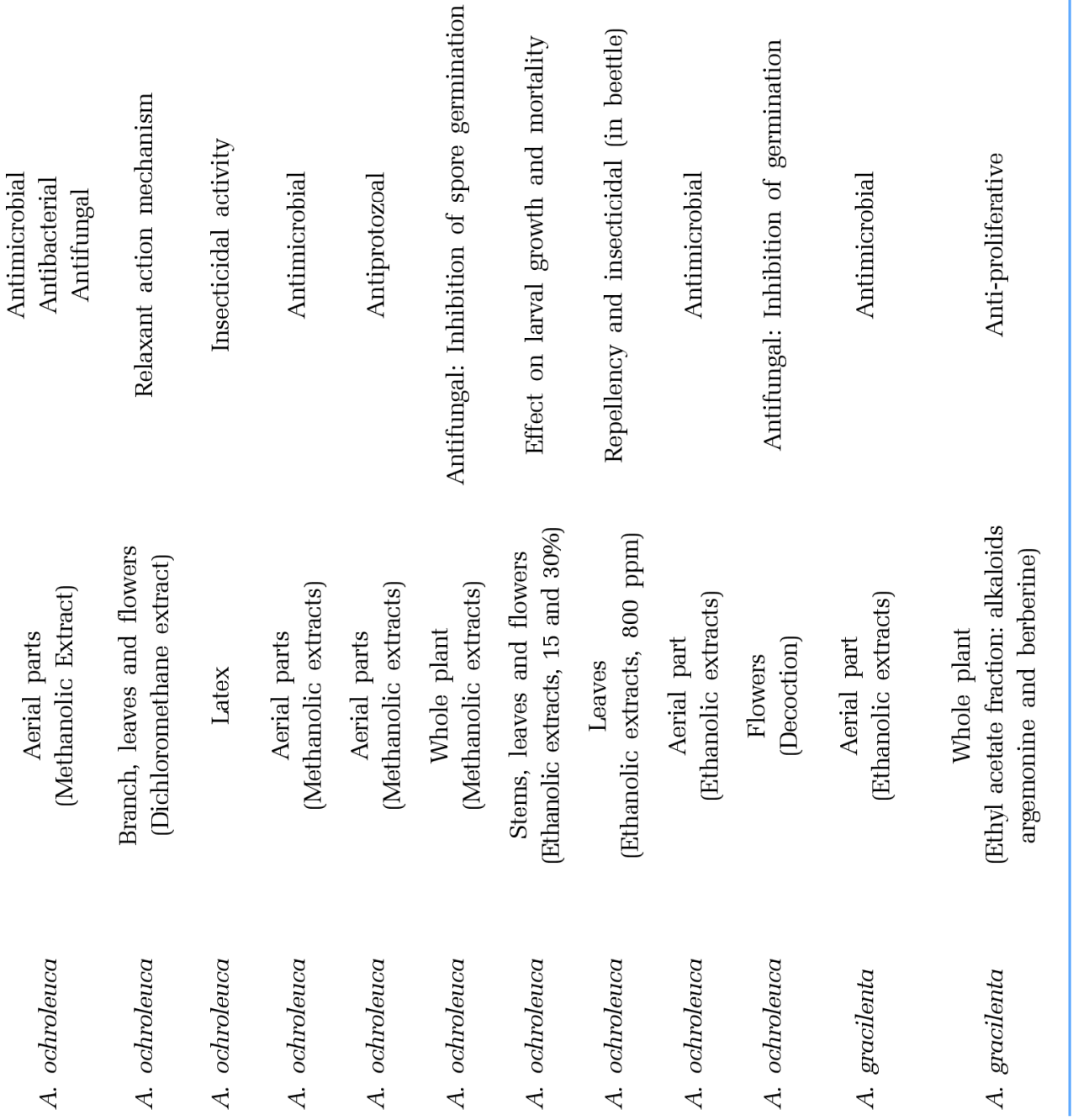




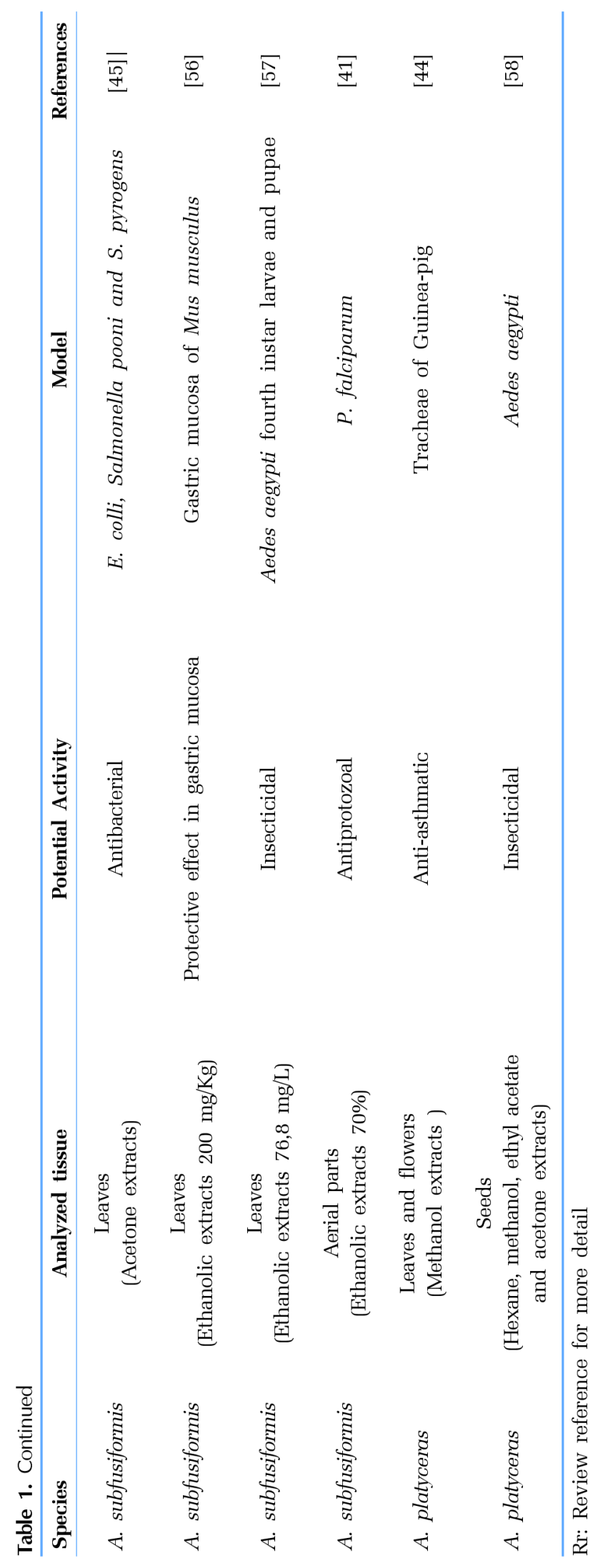

development of Spodoptera frugiperda [53]. The mechanism of action has not been elucidated, but authors suggest that could be due to nervous system toxicity or enzymatic inhibition [57].

Martinez-Tomás et al. [59] reported that the aqueous extract of $A$. mexicana (5\%) has an effect on the whitefly (Bemisia tabaci), reducing the population by $97.6 \%$. Bemisia tabaci is a plague feared due to its high degree of resistance to numerous insecticides and its tendency to transmit viruses [60].

A more detailed review of $A$. mexicana and its biological activities which have been widely published can be found in Sharanappa and Vidyasagar [1], Brahmachari et al. [3], or Rubio-Piña and Vázquez-flota [4].

It is also worthy of note the muscle relaxing potential of leaves and flower extracts of Argemone species (A. mexicana, A. ochroleuca, and $A$. platyceras), which could be used to obtain new drugs to treat the symptoms of asthma [61].

In addition, the crude latex of $A$. ochroleuca shows antifungal, antibacterial, and insecticidal activity [48, 62, 63].

Different authors have investigated the inhibitory effect of $A$. mexicana and $A$. gracilenta extracts on the growth of various cancer cell lines. Studies about the sanguinarine alkaloid located in roots and mature seeds of $A$. mexicana and A. ochroleuca have demonstrated the effect against some human cancer cell lines such as squamous cell carcinoma, pancreatic carcinoma, colorectal cancer, leukemia, bone cancer, bladder cancer, lung, among others [64-72].

\subsection{Alkaloids of Argemone}

The wide variety of biological activities in Argemone species can be attributed to the high content of benzylisoquinoline alkaloids (ABI) such as protopine, berberine, sanguinarine among many others distributed in the different tissues of the plant [3, 35]. ABI are derived from S-norcoclaurine (1-benzylisoquinolines backbone), which is produced by the condensation of 4-hydroxyphenylpyruvate and dopamine [73].

Some ABI produced by Argemone species have been individually evaluated to determine different biological activities such as antibacterial, antiviral, cytotoxic activity, among others $[35,74,75]$.

The mechanism of sanguinarine-induced apoptosis involves the cell death signaling pathway and the ability of the molecule to intercalate in DNA, inhibiting replication. Sanguinarine is a planar molecule of cationic nature, which easily penetrates the membranes, by binding to proteins with negative charge. Its reactivity with the $\mathrm{SH}$ groups of proteins results in the inhibition of cytosolic and membrane enzymes, such as $\mathrm{Na}+\mathrm{K}$ + ATPase [3, 76, 77].

Despite cytotoxicity and DNA damage, sanguinarine has a differential effect on normal and cancer cell proliferation, inducing apoptosis in the latter [64]. Results of toxicology evaluation of a sanguinarine and chelerythrine mixture in pigs suggest daily oral safe doses of up to $5 \mathrm{mg}$ per $\mathrm{kg}$ [78]. An assay on reproductive toxicology of sanguinarine reports maternal oral toxicity of $60 \mathrm{mg} / \mathrm{kg}$ in rats and $25 \mathrm{mg} / \mathrm{kg}$ in rabbits, without selective effect on fertility or fetal and neonatal development [75].

In addition, recent research through molecular docking studies, 
make efforts to search for molecules that may be inhibitors of the SARS-CoV-2 virus that causes the current COVID-19 pandemic, some works have evaluated various alkaloids present in Argemone species [79-81].

Pandeya et al. [80] proposed that $A$. mexicana could be a candidate against the infection, by the inhibition potential of their alkaloids on the RNA-dependent RNA polymerase of SARS-CoV-2. The authors point out the potential of protopine and allocryptopine, with a binding energy of $-6.07 \mathrm{kcal} / \mathrm{mol}$ and $-5.75 \mathrm{kcal} / \mathrm{mol}$, respectively.

On the other hands Agrawal et al. [81] reported the molecular coupling between the COVID-19 Protease enzyme (3cl ${ }^{\text {pro }} / \mathrm{M}^{\text {pro }} \mathrm{PDB}$ ID: 6LU7) with sanguinarine and berberine, the authors mention that although sanguinarine has good binding energy (-7.7720 $\mathrm{kcal} / \mathrm{mol}$ ), the formation of any hydrogen bond with the viral enzyme is not achieved.

\section{Argemone Oil}

The seed oil content in Argemone species is between 30 to $40 \%$ [4, 6-9]. However, these values have been reported strictly to $A$. mexicana and $A$. ochroleuca, and in some cases the species is not defined.

Mariod et al. [29] reported that the seeds of $A$. mexicana have about $35 \%$ oil and $24 \%$ protein, and also contain small amounts of starch and free sugars. The oil is composed mainly of linoleic acid (54\% - 61\%) and oleic acid (21\% - 33\%).

According to Ahmed et al. [42] A. mexicana oil is composed of $90 \%$ triglycerides, $2.3-2.8 \%$ diglycerides and $1.5-1.8 \%$ monoglycerides. Where 92\% are neutral lipids, 5.5 - 5.8\% glycolipids and $1.5 \%-1.7 \%$ phospholipids.

The composition analysis of fatty acids from Argemone spp. has been focused mainly on $A$. mexicana, besides $A$. grandiflora, A. ochroleuca, and A. platyceras.

All reports are in agreement with the presence of linoleic and oleic acids as the main fatty acids, with some variations in the degree of unsaturation, very similar to the oil composition of other vegetable sources, such as sunflower oil [9, 82].

Table 2 shows the fatty acid composition of seed oil reported to different Argemone species, where palmitic acid (7 - 14.7\%), stearic acid (3.8 - 6.75\%), linoleic acid (36.6 - 61.4\%), oleic acid (18.5 - 40\%) and ricinoleic acid (9.8 - 10\%) are mainly present.

There are few reports about the composition of $A$. ochroleuca seed oil. Fatima et al. [18] point out that the main methyl esters of $A$. ochroleuca are: eicosanoate acid (arachidic), palmitate, linoleate, oleate, 9- octadecenoate as the principal of the unsaturated, and methyl decosanoate (behenate) of the saturated. On the other hand, Fletcher et al. [87] reported in A. ochroleuca the composition of methyl esters, including some non-specific compounds (18\% methyl linoleate and stearate) and two unknown components (47 and $26 \%$, respectively) by their HPLC method.

The table includes unpublished data generated by the authors of this work about the fatty acids composition of $A$. ochroleuca seed oil. The obtained profile agrees with previously published works, where mainly linoleic and oleic acid are present.

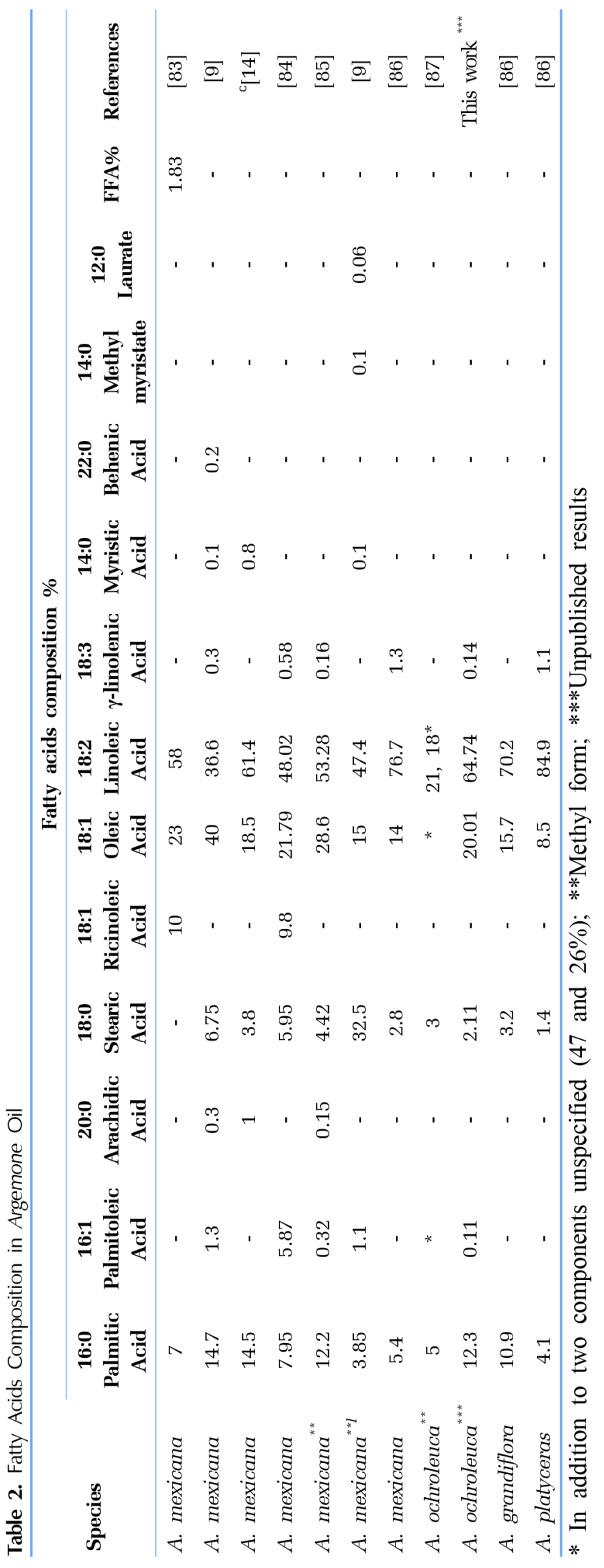




\section{Energy Production}

The use of biofuels is of great interest, given that it originates from renewable sources. Numerous investigations have shown environmental benefits of the use of biodiesel, considering it as a clean fuel, which contributes to the reduction of the emission of toxic gases [88].

However, there are limiting factors for its application, such as high production costs and competition with food source, for this reason, the use of alternative raw materials is important because more than $95 \%$ of the raw materials used for the production of biodiesel come from edible vegetable oils, having an impact on food security [89, 90].

Different works about the use of Argemone species as a raw material with energy potential have been published. The first study to generate and extract esters and biogas from $A$. mexicana seeds was made in 2010 by Singh and Singh [17].

Since then, published papers (from 2010 to 2020) about obtaining biofuels from $A$. mexicana seed oil have been carried out mainly in India, in at least 8 different research centers, and two works carried out in Korea and Pakistan. Those studies reflect the interest in the genus Argemone due to its energetic potential, however, they are mostly exploratory works.

Moreover, the use of $A$. ochroleuca seed oil was reported for the first time in 2017 by Fatima et al. [17] from Quaid-i-Azam University in Pakistan.

The biodiesel obtained showed similar physicochemical properties to conventional fossil fuel [91], such as viscosity, density, calorific value, cetane index, flash point, fire point, and cloud point. Those characterizations are important to understand the quality and stability of methyl esters generated.

In Table 3, physical and chemical properties of the methyl esters from Argemone seed oil produced in different research works are summarized. The table compiles the works related to the use of Argemone seed oil from 2010 to 2019, whether raw, esterified or in mixtures with conventional diesel. Some authors report data of mixtures at $10,20,30,40$, and $100 \%$, of which only the data of the lowest and highest mix have been taken.

It can be seen that the majority of synthesized biodiesel with Argemone seed oil has a density between $860-870 \mathrm{~kg} / \mathrm{m}^{3}$, which decreases when it is blended with petroleum diesel, as reported by Singh and Singh [8] densities of 810 and 790 in mixtures of 50 and $25 \%$, respectively.

The viscosity of esters is slightly greater compared to conventional diesel according to ASTM standard (3.5 - $5 \mathrm{cSt} 40^{\circ} \mathrm{C}$ [9]), however, some papers report viscosity values lower than $5 \mathrm{cSt}$, such as Agarwall et al. (3.94 cSt) [86], Parida et al. (5.07 cSt) [92] and Anjum et al. (5 cSt) [93].

Other authors mentioned that biodiesel blends are an option to reduce these values, such as a $10 \%$ mixture by Singh et al. (3.9 cSt) [83], 24\% by Ilag et al. (2.8 cSt) [94] or $20 \%$ by Parida et al. (4.1 cSt) [95]. The flash and the cloud point of esters are also high, and the biodiesel blends reduce them [8].

In addition to the production of biodiesel, the use of waste for biogas production has been reported by Singh et al. [17], who obtained 52\% methane through the anaerobic digestion of the seed waste generated in a reactor. The caloric content of seed waste was $4,621 \mathrm{kcal} / \mathrm{kg}$.
The vast majority of the reports about the synthesis of biodiesel were performed in $A$. mexicana, except the study of Fatima et al. [18] where a single step transesterification of $A$. ochroleuca oil was made with a yield of $91 \%$.

On the other hand, Table 4 shows the conditions for obtaining the biodiesel generated in Argemone spp., the type of alcohol, the catalyst, the reaction conditions (temperature and time) as well as the yield obtained by different authors.

The biodiesel production from $A$. mexicana oil has been mainly carried out by two-step esterification/transesterification reaction due to the high level of acidity reported by the authors [8, 17], employing an acid catalyst in the first stage and alkaline catalyst in the second stage, with a yield above $90 \%$ and using methanol as synthetic alcohol; whereas Agarwal et al. [86] reported a microwave assisted esterification process with a 91\% yield.

Singh et al. [17] have evaluated the efficacy of ethanol and methanol as synthetic alcohol, obtaining a higher yield with methanol and $\mathrm{NaOH}$ as a catalyst. Moreover, the most commonly used catalyst is sodium hydroxide $(\mathrm{NaOH})$, followed by potassium hydroxide $(\mathrm{KOH})$, and manganese carbonate $\left(\mathrm{MnCO}_{3}\right)$. The best reaction yield (100\%) was obtained by Singh and Singh $[8,17]$ with an alcohol-oil ratio of 5:1 using methanol, $\mathrm{NaOH}$, and 60 minutes of reaction at $55-60^{\circ} \mathrm{C}$. For different reports, the ratio 5:1 was the most used.

\section{Culture of Argemone}

Argemone species are classified as perennial or annual [16, 26, 96]. The persistent primary root or the activation of axillary buds constitute and efficient perenization strategy in some plants [19].

According to Ownbey, in the year 1592 A. mexicana was introduced and cultivated in Europe for the first time, where it was popular in the gardens in the decade of 1830; whereas A. ochroleuca was introduced in 1790 and $A$. grandiflora in 1827 [30].

Argemone species are very versatile due to they can grow under different conditions, in poor soils, with different climatic conditions. For this reason, different plant growth stages can be found, even at the same time $[16,25]$. It has been mentioned that these species bloom throughout summer until autumn. However, blooms of the plant can occur throughout the year. In western Mexico is more common to find developed plants in winter and at the beginning of spring [19, 30, 97].

Argemone species develop a deep primary root after germination, limited by the type of soil and moisture availability [98].

\subsection{Requirements}

The cultivation of $A$. ochroleuca, require well-drained and light soils, this species could be grown in acid, neutral and basic soils, but does not tolerate waterlogged soils. Moussa et al. [16] recorded the characteristics of the localities in Taif Governorate (Saudi Arabia) where grew naturally, they indicated slightly alkaline soils, with a lack of carbonates, high electrical conductivity (EC), and high content of $\mathrm{Ca}^{+2}, \mathrm{Cl}^{-}$and $\mathrm{SO}_{4}^{+2}$.

A. ochroleuca were registered in sites with low phosphorus content, where it also grows well, in the case of $A$. mexicana has preference for sites with nitrogen deficiency [99, 100]. 


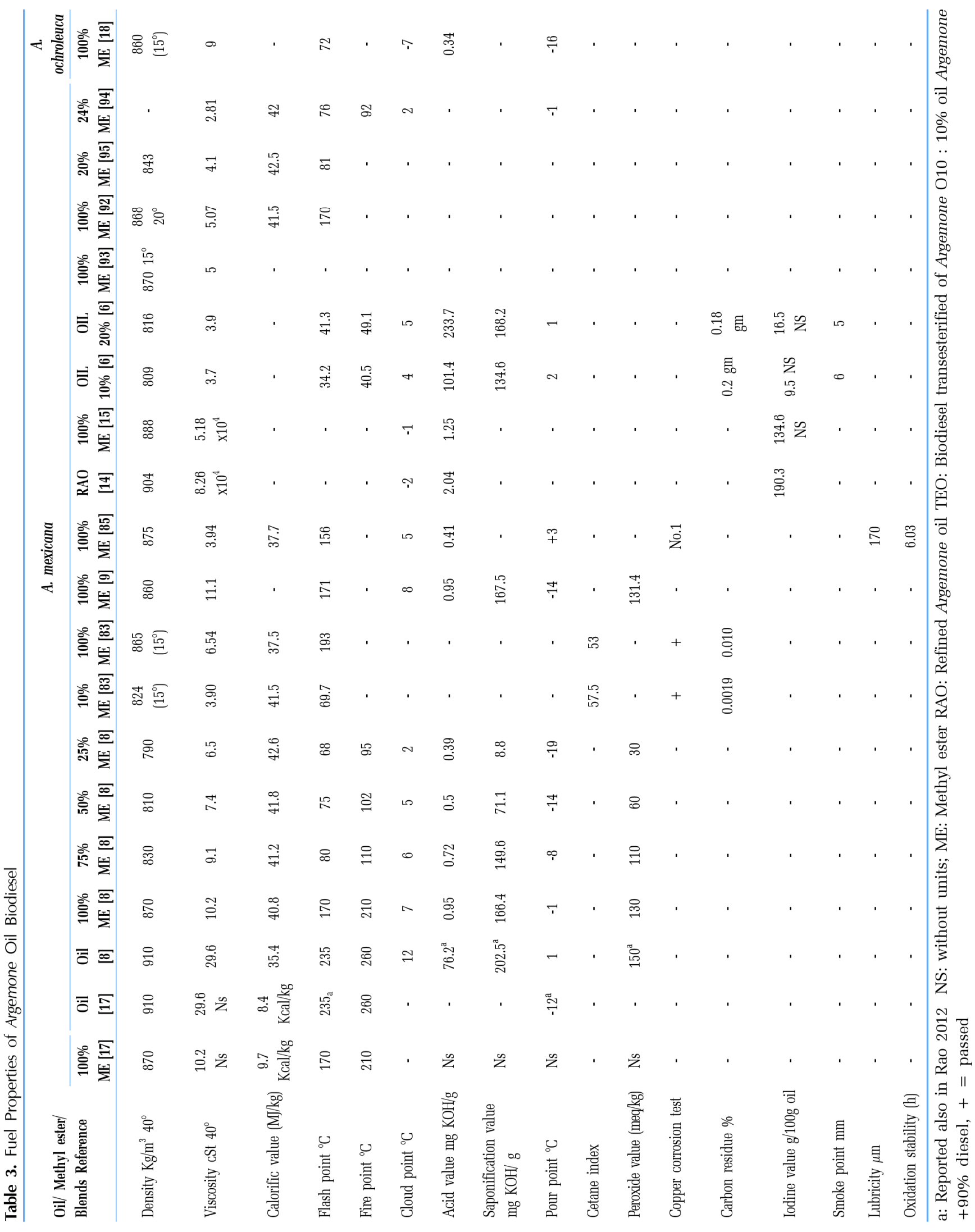




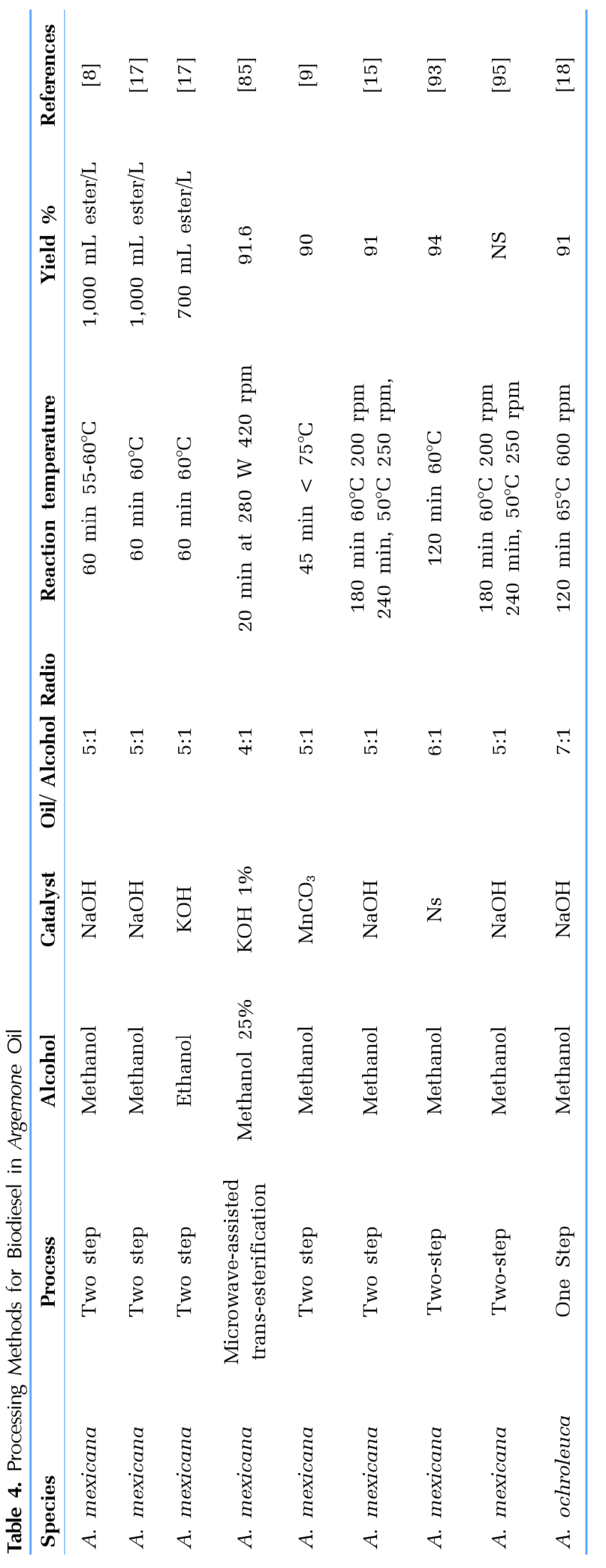

\subsection{Reproduction}

Argemone species reproduce sexually through cross-pollination, and their seeds are dispersed by surface water, agricultural machinery, or animals. Most of the seeds in species such as A. ochroleuca and $A$. mexicana do not germinate immediately after they are released, even until after several years, due to the seeds present morphological dormancy, most seeds germinate until the embryos are developed [98, 101].

The germination of $A$. subfusiformis seeds was observed 10 years after sowing. Several thermal shock treatments have been implemented to break the morphological dormancy in Argemone seeds, including high and low temperatures to break the latency of hypocotyl and epicotyl before germinating [101].

Karlsson et al. [101] evaluate different germination conditions by modifying temperature and light. Maximum germination (100\%) was achieved only in treatments with gibberellic acid and with the elimination of part of the seed coat (scarification). The authors explain that the latency may be due to an inhibiting substance present in the seed.

Moussa et al. [16] reported that the germination of $A$. ochroleuca seeds occurs mainly in December. On the other hand, Serrano-Gamboa [102] indicates a germination rate of $21 \%$ after two weeks; whereas Xool-Tamayo [103, 104] obtained a higher seed germination percentage (60\%) after $3 \mathrm{~d}$ with gibberellic acid treatment.

\section{The Environmental Importance of Argemone spp}

In some countries, Argemone species are considered invasive species that can affect the biodiversity by their allelopathic activity. Also, some species such as $A$. mexicana, due to their toxicity, are seen as very dangerous for livestock and humans for the risk of poisoning from accidental consumption [25, 98].

Despite this, not all species have the same toxicity, it has even been mentioned that some animals have fed on Argemone plants without any impact on their health. In Madagascar, the native lemur species were observed feeding on Argemone stems in a period of insufficient resources [5]. In Mexico, A. ochroleuca was mentioned in 3 sites in the region of the Valley of Mexico as a forage plant [105].

In addition, the multiple biological activities of Argemone species allow the use of its compounds for the biological control of other weeds or numerous pests, resulting in a positive environmental benefit. Abd-elgawad et al. [106] described the phytotoxic potential of the essential oil of $A$ ochroleuca, therefore, its use as a bioherbicide could be an environmentally friendly option that counteracts the negative environmental and human health impacts caused by the use and accumulation of synthetic agrochemicals.

On the other hand, the biofuels implementations that can be obtained from Argemone oil provide environmental benefits as discussed in previous sections. This can be further improved by the chemical profile of these species and their high-value by-products, besides the growing conditions of these plants, which have low water requirements and can take advantage of nutrient-poor soils, without competing with food crops generating the possibility to make barren lands productive and even to grow sustainable crops [8, 15, 18]. 


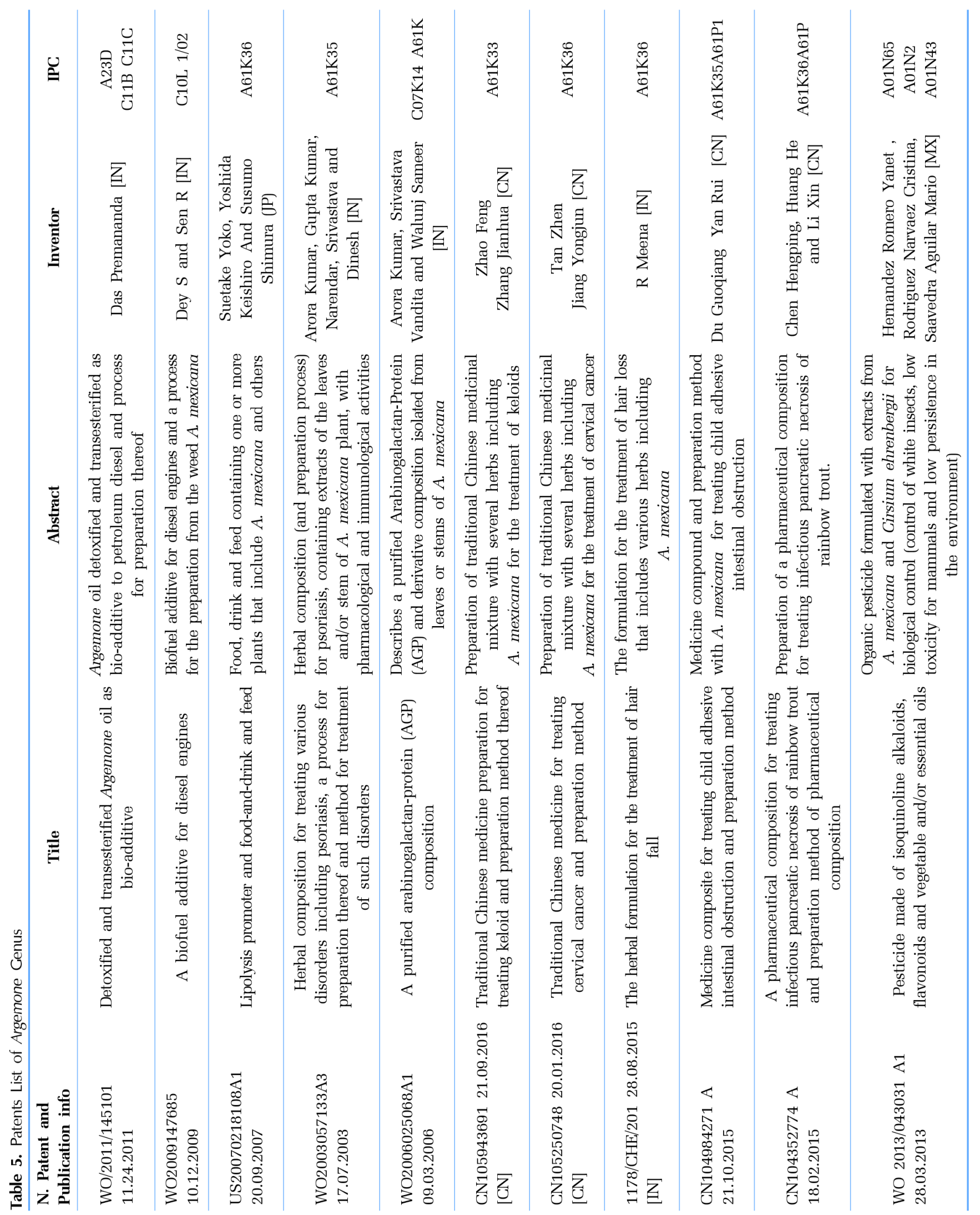




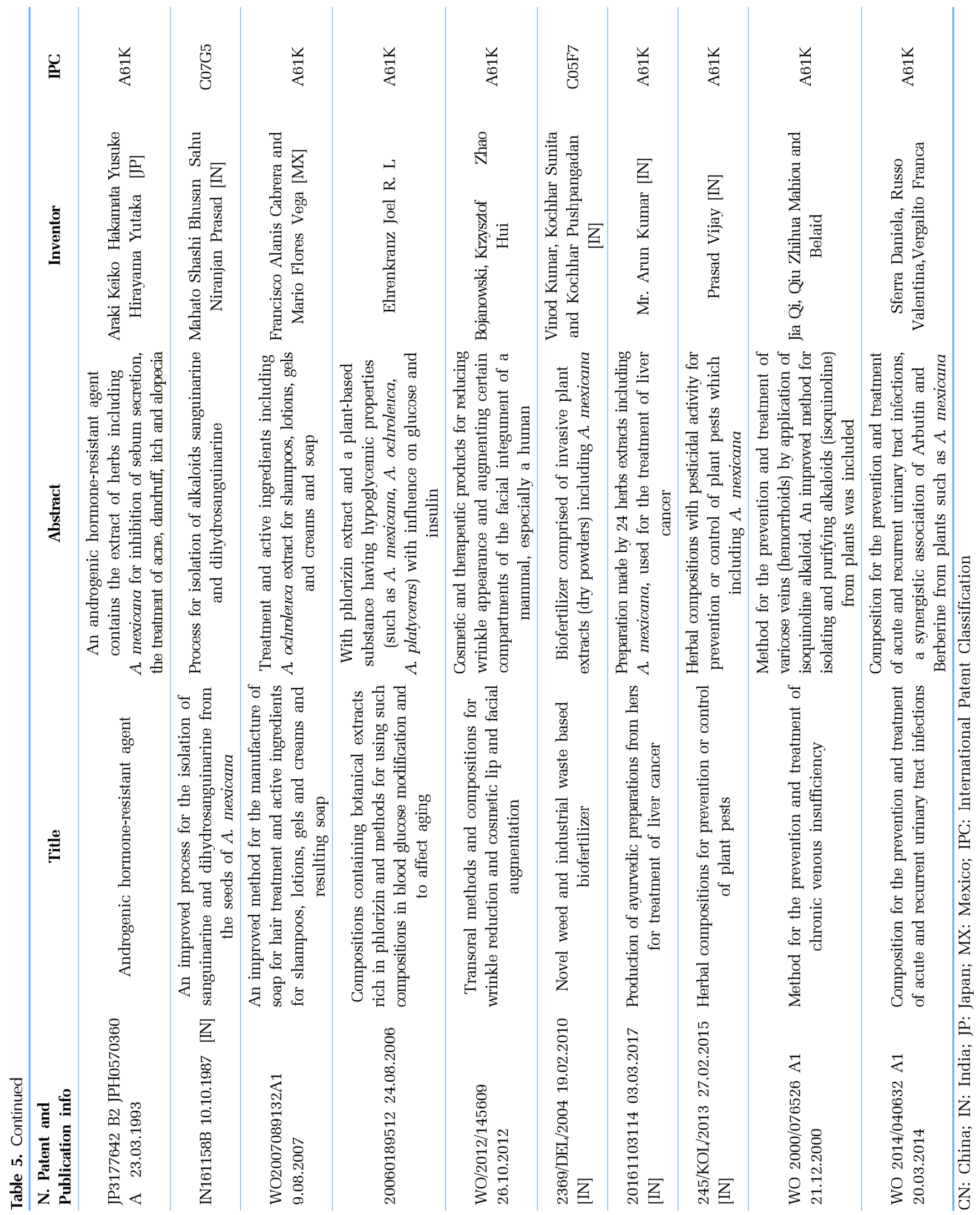




\section{Registered Intellectual Property Rights}

The search of the state of intellectual property related to Argemone genus was performed using search engines of the World Intellectual Property Organization (WIPO-PATENTSCOPE), LENS, ESPACENET, and Google Patents.

For the patent search, the word "ARGEMONE" as a title, abstract or claims were used. For LENS, 123 results were obtained with these criteria, patents included in the jurisdiction of WIPO were selected, and according to LENS were 25 patents. The search was complemented with other search engines, selecting other patents of the local jurisdiction. The results are summarized in Table 5.

Most of the patents reported are included in the A61K classification, which refers to preparations for medical, dental, or toilet purposes. These patents protect mainly herbal formulations with different plants including some species of Argemone (A. mexicana, A. ochroleuca, and A. platyceras).

Most of these herbal preparations have pharmaceutical applications, such as hypoglycemic or lipolytic effect. As well as for the treatment of dermal diseases, cancer, and other cosmetics treatments such as hair loss.

The main countries with patents related to Argemone species are India, China, and the United States. $A$. mexicana is the main species described in these patents, $A$. ochroleuca, and $A$. platyceras are mentioned only in 2 patents (20060189512 and WO2007089132 A1).

Furthermore, only two patents were found in the energy sector, which refers to bioadditives prepared from $A$. mexicana oil to mix with diesel.

\section{Conclusions}

The genus Argemone includes several weed species of great importance due to the presence of benzylisoquinoline alkaloids produced in different tissues of the plant, which have important biological and physiological properties widely reported. Many of these alkaloids inhibit the growth of different microorganisms, which is promising for new drug development, such as antibiotics.

Due to the effect of extracts of different Argemone species against important pathogens or diseases such as malaria, or the cytotoxic activity in different cancer cells lines, they are a candidate for the isolation of new compounds that have not yet been elucidated and that could contribute to an advance in these health problems. Furthermore, the economic potential is evident for the manufacture of natural herbicides and pesticides that can provide protection against a variety of pests affecting commercial crops.

On the other hand, due to the high content of oil in the seeds, several authors have considered its potential use in the energy sector. Thus the integral potential use of the bioactive compounds and the oil of the seeds of the Argemone species could generate a strategy that contributes to improve the quality of life of small farm communities through the sustainable production and marketing of unconventional high valuable raw material for the chemical, pharmaceutical, and energy sectors. Furthermore, the low nutritional requirements or demand for water in the cultivation of these species make the Argemone crop an option with competitive advantages for the production of biofuels such as biodiesel.

The previous works reported, as well as the different patents that have been generated indicate the potential of the Argemone species, at the same time, it is clear that there is still a long way to go in improving the production of energy products, as well as in the investigation of new biological activities of species that have not yet been studied.

The potential of Argemone species also requires exploring more about their crop and management; in order to improve the yields generated in oil and secondary metabolites. Opening the possibilities for breeding programs for these species for various applications: ornamental, pharmaceutical, energy, or biological control purposes.

\section{Acknowledgments}

The authors would like to thank financial support from the National Council of Science and Technology in Mexico (Consejo Nacional de Ciencia y Tecnologia, CONACYT) for the support given. As well as Laura Díaz Godinez for technical support in the area of microscopy and Dr. Luis Mojica for the guidance provided for the preparation of this work.

\section{Author Contributions}

M.D.A.A. (Ph.D. student) developed the original idea and wrote the manuscript. DA.J. (Ph.D.) fully revised the manuscript. L.M.J. (Ph.D.) revised plant's phytochemical section. M.JC. (Ph.D.) revised oil and biodiesel section. G.M.A (Ph.D.) revised botanical and agronomy section. C.N.J. (Ph.D.) revised manuscript and did technical support in the area of microscopy.

\section{References}

1. Sharanappa R, Vidyasagar G. Plant profile, Phytochemistry and Pharmacology of Argemone mexicana Linn. A review. Int. J. Pharm. Pharm. Sci. 2014;6:45-53.

2. Hassan S. Positive aspects of weeds as herbal remedies and medicinal plants. J. Res. Weed Sci. 2020;3:57-70.

3. Brahmachari G, Gorai D, Roy R. Argemone mexicana: Chemical and pharmacological aspects. Brazilian J. Pharmacogn. 2013;23: 559-575.

4. Rubio-Piña J, Vazquez-Flota F. Pharmaceutical applications of the benzylisoquinoline alkaloids from Argemone mexicana L. Curr. Top Med. Chem. 2013;13:2200-2207.

5. Alam A, Khan A. Argemone mexicana L: A weed with versatile medicinal and pharmacological applications. Ann. Phytomedicine. 2020;9:218-223.

6. Ariharan V, Kumar S, Devi V, Prasad P. Studies On Argemone mexicana Oil For Its Usage As Biodiesel. Int. J. Pharma Bio Sci. 2014;5:528-532.

7. Singh S, Singh T, Singh V, Pandey V. Quaternary alkaloids of Argemone mexicana. Pharm. Biol. 2010;48:158-160.

8. Singh D, Singh S. Low cost production of ester from non edible 
oil of Argemone mexicana. Biomass. Bioenergy. 2010;34:545-549.

9. Rao R, Zubaidha P, Kondhare D, et al. Biodiesel production from Argemone mexicana seed oil using crystalline manganese carbonate. Polish J. Chem. Technol. 2012;14:65-70.

10. Singh S, Singh A, Keshariwala M, et al. The mixture of tertiary and quaternary alkaloids isolated from Argemone ochroleuca inhibits spore germination of some fungi. Arch. Phytopathol Plant Prot. 2010;43:1249-1253.

11. Moustafa M, Alamri S, Taha T, et al. In vitro antifungal activity of Argemone ochroleuca Sweet latex against some pathogenic fungi. African J. Biotechnol. 2013;12:1132-1137.

12. Guil-Guerrero J, Guil-Laynez J, Guil-Laynez A. Bioprospecting for seed oils from wild plants in the Mediterranean Basin for biodiesel production. J. Clean. Prod. 2017;159:180-193.

13. Gaurav N, Sivasankari S, Kiran G, et al. Utilization of bioresources for sustainable biofuels: A Review. Renew. Sustain Energy Rev. 2017;73:205-214.

14. Atabani A, Silitonga A, Ong H, et al. Non-edible vegetable oils: A critical evaluation of oil extraction, fatty acid compositions, biodiesel production, characteristics, engine performance and emissions production. Renew. Sustain Energy Rev. 2013;18:211-245.

15. Pramanik P, Das P, Kim P. Preparation of biofuel from Argemone seed oil by an alternative cost-effective technique. Fuel 2012;91:81-86.

16. Moussa A, Bazaid S, Muneera S. Vegetation strategies of invasive Argemone ochroleuca sweet in different habitats in Taif Governorate, Saudi Arabia. African J. Agric Research. 2012;7: 4771-4781.

17. Singh D, Singh S, Prerna P. Production of both esters and biogas from Mexican poppy. Sci. Technol. 2010;4:866-871.

18. Fatima A, Zafar M, Ahmad M, et al. Parametric characterization and statistical optimization of Argemone ochroleuca (Mexican Poppy) methyl esters as a renewable source of energy. Energy Source. Part A Recover Util. Environ. Eff. 2017;39:1963-1969.

19. Ownbey G. Monograph of the genus Argemone for North America and the West Indies. Memoirs. Torrey Botanical Club. 1958;21: 1-159.

20. Vibrans H. Malezas de México CONABIO [Internet]. Conabio: Vibrans H; c2017. [Cited 12 october 2017]. Available from: http://www.conabio.gob.mx/malezasdemexico/papaveraceae/argemone-mexicana/fichas/ficha.htm.

21. Karnawat M, Malik C. Determination of nature of polyploidy in Argemone ochroleuca ssp. ochroleuca Sweet. Nucl. 2011;54: 153-158.

22. Peña R. El género Argemone (Papaveraceae) en Chile. Rev. Chil. Flora y Veg. Chloris Chil. 2002;5:1.

23. Zolla C, Argueta A. Biblioteca digital de la medicina tradicional mexicana. [Internet]. Landsteiner Sci. Com. Nac. para el Desarro. Los Pueblos Indígenas. Programa Universitario México Nación Multicultural; 2009. [Cited 12 November 2019]. Available from: http://www.medicinatradicionalmexicana.unam.mx/index.

24. Reveles F, Rosales R. Identification of plant species with potential use in liquid biofuels. Rev Mex Ciencias Agrícolas. 2010; 1:45-54.

25. Assaeed A, Al-Rowaily S, El-Bana M, et al. Functional Traits Plasticity of the invasive herb Argemone ochroleuca Sweet in different arid habitats. Plants. 2020;9:1-16.

26. Rzedowski G. Papaveraceae. Flora Del Bajío Y De Regiones Adyacentes. Fascículo. 1991;157:1-166.

27. Martinez-Ojeda E. Papaveraceae. In: Gómez A, eds. Flora de Veracruz. Veracruz: Instituto Nacional de investigaciones sobre recursos bióticos; 1982. p. 1-15.

28. Mirtadzadini M, Akbari F, Hatami E. Argemone (papaveraceae), a new genus for the flora of Iran. Iran J. Bot. 2016;22:79-81.

29. Mariod A, Mirghani M, Hussein I. Argemone mexicana (Argemone Seed). In: Mariod AA, Mirghani M, Hussein I, eds. Unconventional Oilseeds and Oil Source. London: Academic Press; 2017. p. 9-12.

30. Hernández-Ruiz J, Bernal J, Gonzales-Castañeda J, et al. Argemone ochroleuca: (Papaveraceae), alkaloid potential source for agricultural and medicinal uses. Trop. Subtrop. Agroecosystems. 2020;23:1-13.

31. Lei Y, Liu L, Tang X, et al. Sanguinarine and chelerythrine: two natural products for mitochondria-imaging with aggregation induced emission enhancement and $\mathrm{pH}$-sensitive characteristics. R. Soc. Chem. 2018;8:3919-3927.

32. Yuan F, Chen M, Leng B, et al. An efficient autofluorescence method for screening Limonium bicolor mutants for abnormal salt gland density and salt secretion. S. Afr. J. Bot. 2013;88: 110-117.

33. Yang L, Wen KS, Ruan X, et al. Response of plant secondary metabolites to environmental factors. Molecules 2018;23:1-26.

34. Rose J. The Mexican species of Argemone. Cont. U.S. Nat. Herb. 1903;8:23-27.

35. Rubio-piña J, Vázquez-flota F. Pharmaceutical Applications of the benzylisoquinoline alkaloids from Argemone mexicana. Curr. Top Med. Chem. 2013;13:2200-2207.

36. Vázquez-Alonso M, Bye R, Pulido-Salas M, et al. Etnobotánica de la Cultura Teotihuacana. Bot. Sci. 2014;92:563-574.

37. Reyes F, Jimena C, Canales M, et al. Antimicrobial activity of Argemone ochroleuca Sweet (Chicalote). Boletín Latinoam y del Caribe Plantas Med y Aromáticas. 2011;10:139-146.

38. Guillen J, Aguilar S, Quiroga M, et al. Uso de herbolaria para afecciones bucales en una población de Nayarit, México. In: 3rd Simposio Nacional de Ciencias Farmacéuticas y Biomédicina; 1-2 September 2016; México. p. 16.

39. Gobato R, Gobato A, Gobato-Fedrigo D. Molecular geometry of alkaloids present in seeds of mexican prickly poppy. Quant. Biol. Other Quant. Biol. 2015;1-11.

40. Rondina R, Bandoni A. Medicinal Species with Potential Analgesic Activity. Dominguezia 2008;24:47-70.

41. Bourdy G, Oporto P, Gimenez A, Deharo E. A search for natural bioactive compounds in Bolivia through a multidisciplinary approach: Part VI. Evaluation of the antimalarial activity of plants used by Isoceño-Guaraní Indians. J. Ethnopharmacol. 2004;93:269-277.

42. Ullah R, Alqahtani AS, Noman OMA, et al. Saudi Journal of Biological Sciences A review on ethno-medicinal plants used in traditional medicine in the Kingdom of Saudi Arabia. Saudi J. Biol. Sci. 2020;27:2706-2718.

43. Deka S, Deka S. Survey of medicinal plants used against leprosy disease by the tribal (Lalung) people of Myong area of Morigaon District, Assam, India. Plant Arch. 2007;7:653-655. 
44. Fernandez J, Reyes R, Ponce $\mathrm{H}$, et al. Isoquercitrin from Argemone platyceras inhibits carbachol and leukotriene D4-induced contraction in guinea-pig airways. Eur. J. Pharmacol. 2005;522: 108-115.

45. Jimoh F, Adedapo A, Aliero A, et al. Polyphenolic and biological activities of leaves extracts of Argemone subfusiformis (Papaveraceae) and Urtica urens (Urticaceae). Rev. Biol. Trop. 2010;58:1517-1531.

46. Leyva-peralta M, Robles R, Garibay A, et al. In vitro anti-proliferative activity of Argemone gracilenta and identification of some active components, BMC Complement. Altern. Med. 2015;15:13-19.

47. Encarnación R, Virgen M, Ochoa N. Antimicrobial Activity Of Medicinal Plants From Baja California Sur (México). Pharm. Biol. 1998;36:33-43.

48. Alamri S, Moustafa M. Antibacterial activity of the latex of Argemone ochroleuca sweet. Saudi Med. J. 2010;31:1207-1210.

49. Sánchez-Mendoza ME, Castillo-Henkel C, Navarrete A. Relaxant action mechanism of berberine identified as the active principle of Argemone ochroleuca Sweet in guinea-pig tracheal smooth muscle. J. Pharm. Pharmacol. 2008;60:229-236.

50. Upadhyay R. Botanicals; Its Safe Use in Pest Control and Environmental Management. Int. J. Zool. Investig. 2016;2:58-102.

51. Abdel-sattar E. Antimicrobial Activity of Extracts of some Plants Collected from the Kingdom of Saudi Arabia. JKAU Med. Sci. 2008;15:25-33.

52. Abdel-sattar E, Maes L, Salama M. In Vitro Activities of Plant Extracts from Saudi Arabia against Malaria, Leishmaniasis, Sleeping Sickness and Chagas Disease. Phytother. Res. 2010;24: 1322-1328.

53. Martínez M, Aguado-Pedraza AJ, Gómez B, et al. Effects of Ethanolic Extracts of Argemone ochroleuca (Papaveraceae) on the Food Consumption and Development of Spodoptera frugiperda (Lepidoptera: Noctuidae). Florida Entomol. 2017;100:339-345.

54. Bakhashwain A, Alqurashi A. Repellent and Insecticidal Effects of Some Plant Extracts on Flour Beetle Tribolium castaneum Herbst (Coleoptera: Tenebrionidae). Alexandria Sci. Exch. J. 2010;31:248-254.

55. Valdez S. Efecto de siete especies de plantas medicinales sobre el crecimiento de hongos de importancia para la inocuidad alimentaria [dissertation]. México: Univ. Autónoma de Querétaro; 2014.

56. Torres D. Efecto protector del extracto hidralcoholico de hojas de Aloe vera y Argemone subfusiformis Own. en lesiones gástricas inducidas con etanol en Mus musculus BALB/C [dissertation]. Peru: Univ. Nacional De Trujillo; 2014.

57. Vidal J, Carbajal A, Sisniegas M, Bobadilla M. Efecto tóxico de Argemone subfusiformis Ownb y Tagetes patula Link sobre larvas del IV estadio y pupas de Aedes aegypti L. Rev. Peru. Biol. 2009;15:103-109.

58. Mendoza-Hernández F. Evaluación biocida de extractos de las semillas de las plantas Argemone mexicana y Argemone platyceras, contra el vector transmisor del dengue: Aedes aegypti [dissertation]. México: Instituto Politecnico Nacional;2013.

59. Martinez-Tomás S, Rodríguez-Hernández C, Pérez-Pacheco R, et al. Evaluación de tres extractos vegetales en la población de mosca blanca en el cultivo orgánico de jitomate en invernadero. Entomol. Mex. 2015;2:371-375.

60. De Barro P, Shu-Sheng L, Boykin L, et al. Bemisia tabaci: A Statement of Species Status. Annu. Rev. Entomol. 2010;56:1-19.

61. Anarthe S, Chaudhari S. Neuropharmacological study of Argemone mexicana Linn. J. Appl. Pharm. Sci. 2011;1:121-126.

62. Upadhyay R. Plant latex: A natural source of pharmaceuticals and pesticides. Int. J. Green Pharm. 2011;5:169-169.

63. Moustafa M, Alamri S, Taha T, et al. In vitro antifungal activity of Argemone ochroleuca Sweet latex against some pathogenic fungi. African J. Biotechnol. 2013;12:1132-1137.

64. Ahmad N, Gupta S, Husain M, et al. Differential Antiproliferative and Apoptotic Response of Sanguinarine for Cancer Cells \& Normal Cells. Clin. Cancer Res. 2000;6:1524-1528.

65. Ahsan H, Reagan-Shaw S, Breur J, Ahmad N. Sanguinarine induces apoptosis of human pancreatic carcinoma AsPC-1 and BxPC-3 cells via modulations in Bcl-2 family proteins. Cancer Lett. 2007;249:198-208.

66. Gobato R, Heidari A. Infrared Spectrum and Sites of Action of Sanguinarine by Molecular Mechanics and ab initio Methods. Int. J. Atmospheric Oceanic Sci. 2018;2:1-9.

67. Gong X, Chen Z, Han Q, et al. Sanguinarine triggers intrinsic apoptosis to suppress colorectal cancer growth through disassociation between STRAP and MELK. BMC Cancer. 2018;18:578-578.

68. Kuttikrishnan S, Siveen K, Prabhu K, et al. Sanguinarine suppresses growth and induces apoptosis in childhood acute lymphoblastic leukemia. Leuk. Lymphoma. 2019;60:782-794.

69. Niu X, Fan T, Li W, et al. The anti-inflammatory effects of sanguinarine and its modulation of inflammatory mediators from peritoneal macrophages. Eur. J. Pharmacol. 2012;689: 262-269.

70. Han M, Park C, Jin C, et al. Apoptosis Induction of Human Bladder Cancer Cells by Sanguinarine through Reactive Oxygen Species-Mediated Up-Regulation of Early Growth Response Gene-1. PLoS One. 2013;8:1-10.

71. Park H, Bergeron E, Senta H, et al. Sanguinarine induces apoptosis of human osteosarcoma cells through the extrinsic and intrinsic pathways. Biochem. Biophys. Res. Commun. 2010;399 446-451.

72. Laines-Hidalgo J, Monforte-González M, Vazquez-Flota F. Análisis de la síntesis de alcaloides en semillas y frutos de Argemone mexicana. Rev. Del. Cent. Grad. e Investig. Del. Inst. Tecnológico Mérida. 2018;33:47-49.

73. Beaudoin G, Facchini P. Benzylisoquinoline alkaloid biosynthesis in opium poppy. Planta 2014;240:19-32.

74. Wink M. Modes of Action of Herbal Medicines and Plant Secondary Metabolites. 2015;2:251-286.

75. Mackraj I, Govender T, Gathiram P. Sanguinarine. Cardiovasc. Ther. 2008;26:75-83.

76. Singh N, Sharma B. Toxicological Effects of Berberine and Sanguinarine. Front. Mol. Biosci. 2018;5:1-7.

77. Weiss D, Baumert A, Vogel M, et al. Sanguinarine reductase, a key enzyme of benzophenanthridine detoxification. Plant Cell Environ. 2006;29:291-302.

78. Kosina P, Walterova D, Ulrichova J, et al. Sanguinarine and chelerythrine: assessment of safety on pigs in ninety days feeding experiment. Food Chem Toxicol. 2004;42:85-91. 
79. Khaerunnisa S, Kurniawan H, Jember UM, et al. Potential inhibitor of COVID-19 main protease (Mpro) from several medicinal Plant Compounds by Molecular Docking Study. Preprint. 2020;20944:1-14.

80. Pandeya KB, Ganeshpurka A, Kumar M. Natural RNA dependent RNA polymerase inhibitors : Molecular docking studies of some biologically active alkaloids of Argemone mexicana. Med. Hypotheses. 2020;144:109905.

81. Agrawal A, Jain N, Kumar N, Kulkarn G. Molecular docking study to identify potential inhibitor of Covid-19 main protease enzyme: an in-silico approach. Chemrxiv. Preprint. 2020.

82. Rao R, Zubaidha P, Reddy N, et al. Crystalline manganese carbonate a green catalyst for biodiesel production. Green Sustain. Chem. 2012;2:14-20.

83. Singh M, Gandhi S, Mahla S. Experimental investigations on performance and emission characteristics of variable speed multi-cylinder compression ignition engine using Diesel /Argemone biodiesel blends. Energy Explor. Exploit. 2018;36:1-21.

84. Narayana I, Sudborough J, Ramaswamy A. Argemone oil. J. Indian Inst. Sci. 1925;13:29-38.

85. Agarwal S, Chhibber V, Bhatnagar A, et al. Physico-chemical and tribological studies of Argemone biodiesel synthesized using microwave technique. Curr. Sci. 2017;113:938-941.

86. Marin P, Sajdl V, Kapor S. Fatty acid composition of seeds of the Papaveraceae and Fumariaceae. Phytochemistry 1989;28: 133-137.

87. Fletcher M, Takken G. Isoquinoline Alkaloids and Keto-Fatty Acids of Argemone ochroleuca and A. mexicana (Mexican Poppy) Seed. Aust. J. Agric. Res. 1993;44:265-275.

88. Zunta R, Da Silva L, Marcucci S. Biodiesel production from Jatropha curcas L. oil by simultaneous esterification and transesterification using sulphated zirconia. Catal. Today. 2017;289:105-114.

89. Ahmad A, Yasin N, Derek C, Lim J. Microalgae as a sustainable energy source for biodiesel production: A review. Renew. Sustain. Energy Rev. 2011;15:584-593.

90. Dias J, Alvim-Ferraz M, Almeida M, et al. Selection of heterogeneous catalysts for biodiesel production from animal fat. Fuel 2012;94:418-425.

91. Porte A, Schneider R, Kaercher J, et al. Sunflower biodiesel production and application in family farms in Brazil. Fuel 2010;89:3718-3724.

92. Parida M, Joardar H, Rout A, et al. Multiple response optimizations to improve performance and reduce emissions of Argemone Mexicana biodiesel-diesel blends in a VCR engine. Appl. Therm. Eng. 2019;148:1454-1466.
93. Anjum S, Prakash O, Pal A. Conversion of non-edible Argemone Mexicana seed oil into biodiesel through the transesterification process. Energy Sources, Part A Recover. Util. Environ. Eff. 2018;1:1-8.

94. Ilag P, Khatal S, Mhaske S. The impact of biofuel on IC engine and the environment. Combustion 2018;5:3255-3259.

95. Parida M, Rout A. Combustion analysis of Argemone mexicana biodiesel blends. Energy Sources, Part A Recover. Util. Environ. Eff. 2017;39:698-705.

96. Haisová K, Slavík J. Alkaloids of the Papaveraceae. IL. On alkaloids from Argemone ochroleuca sweet. Collect. Czechoslov. Chem. Commun. 1973;38:2307-2312.

97. Vélez J. CABI: Argemone Mex [Internet]. Vélez J; c2017. [Cited 12 October 2017]. Available from: http://www.cabi.org/isc/datasheet/6878.

98. Moshia ME, Newete S. Mexican poppy (Argemone mexicana) control in cornfield using deep learning neural networks: a perspective. Acta Agric. Scand. Sect. B. Soil Plant Sci. 2019;69: 228-234.

99. Parsons W, Cuthbertson E. Noxious weeds of Australia, Melbourne. 2nd ed. Australia: Csiro Publishing; 2001. p. 534-538.

100. Ramakrishnan P, Gupta U. Nutrient factors influencing the distribution of two closely related species of Argemone. Weed Res. 1972;12:234-240.

101. Karlsson L, Tamado T, Milberg P. Seed dormancy pattern of the annuals Argemone ochroleuca and A. mexicana (Papaveraceae). Flora 2003;198:329-339.

102. Serrano G. Establecimiento de cultivos in vitro de Argemone mexicana L. para el estudio de la biosíntesis de alcaloides bencilisoquinolínicos [dissertation]. México: Centro de Investigación Científica de Yucatán; 2015.

103. Xool J, Monforte M, Rubio-Piña J, et al. Early developmental onset of alkaloid biosynthesis in Mexican poppy (Argemone mexicana L) Papaveraceae. Phytochem. Lett. 2017;20:300-305.

104. Xool J, Serrano G, Monforte M, et al. Development of newly sanguinarine biosynthetic capacity in in vitro rootless shoots of Argemone mexicana L. Mexican prickly poppy. Biotechnol. Lett. 2017;39:323-330.

105. Espinosa-García F, Díaz-Perez R. El uso campesino de plantas arvenses como forraje en el valle de Mexico. Etnoecológica 1996;3:84-94.

106. Abd-elgawad A, Assaeed A, Al-rowaily S, et al. Essential Oil Enriched with Oxygenated Constituents from Invasive Plant Argemone ochroleuca Exhibited Potent Phytotoxic Effects. Plants 2020;9:1-13. 